DOI: https://doi.org/10.35619/iiu.v0i9.8

Денисова Світлана

викладач іноземної мови

Луцького педагогічного коледжу,

м. Луцьк, Україна

ORCID:0000-0001-9352-7036

e-mail:1denusova.svitlana@ukr.net

Кузьмич Оксана

викладач іноземної мови

Луцького педагогічного коледжу,

м. Луцьк, Україна

ORCID: 0000-0002-1335-3791

e-mail:kuzmych.o@ukr.net

Ніколасва Ірина

викладач іноземної мови

Луцького педагогічного коледжу,

м.Луцьк, Україна

ORCID:0000-0002-2949-0002

e-mail:iri5272@ukr.net

\title{
ПОГЛЯДИ В. О. СУХОМЛИНСЬКОГО НА МІЖКУЛЬТУРНУ КОМПЕТЕНТНІСТЬ ВЧИТЕЛЯ ІНОЗЕМНИХ МОВ
}

Анотація. Стаття присвячена поняттю міжкультурної компетентністі в процесі професійної підготовки вчителя іноземної мови. Під час дослідження виявлено основні складові компоненти міжкультурної компетентності: мотиваційний, когнітивний, культурологічний. У статті зазначено, що підготовка сучасного вчителя іноземної мови в європейських країнах, та в Україні, зокрема, повинна мати виражений культурологічний характер i спрямовуватись на формування здібностей адаптивної поведінки в спілкуванні з носіями культури країни, мова якої вивчається. Водночас підготовка вчителя іноземної мови має бути зоорієнтована на формування ментальності, стилю поведінки, традицій і звичаїв народу на основі знання мови. Розглянуто ідеї Василя Сухомлинського щодо змісту та розвитку міжкультурної компетентності вчителя іноземної мови. За висловом педагога, іноземна мова відіграє важливе значення в процесі навчання: виступає умовою гармонійного розвитку кожного учня, необхідна учневі як джерело розвитку його індивідуальних нахилів, здібностей. Вивчення іноземної мови, за словами Сухомлинського, повинно сприяти тому, щоб краще розуміти чужий світ i культуру, а водночас чіткіше відчувати власну ідентичність, належність до єдиного національного простору. Також розкрито погляди вченого на значення культури та іноземної мови в процесі навчання та виховання, які використовують сучасні педагоги для розвитку міжкультурної компетентності сучасного вчителя іноземної мови.

Ключові слова: культура, міжкультурна компетентність, учитель, іноземна мова, культурологічний підхід, комунікація. 
Постановка проблеми. Проблема підготовки педагогічних кадрів нової генерації в контексті гуманізації і демократизації освіти в країні постає сьогодні особливо гостро й пов'язана 3 тенденціями розвитку світового співтовариства. В умовах нової освітянської парадигми підготовка вчителів іноземної мови нового типу стає найважливішою умовою відродження не тільки освіти, але й усієї вітчизняної культури, іiі інтеграції в європейське співтовариство. За таких умов великого значення набуває проблема професійної підготовки вчителя іноземної мови до участі в розмаїтті міжкультурної взаємодії. Підготовка сучасного вчителя іноземної мови як у європейських країнах,так і в Україні має грунтуватися на культурологічному підході і спрямовуватися на формування здібностей адаптивної поведінки в спілкуванні 3 носіями культури країни, мова якої вивчається, а також формування ментальності на основі знання мови, стилю поведінки, традицій і звичаїв народу. 3 огляду на завдання 3 професійної підготовки фахівців педагогічної професії у сфері іншомовної освіти важливо розглядати формування у студентів міжкультурної компетентності як невід’ємної частини професійної компетентності вчителя іноземної мови.

Аналіз останніх досліджень з проблеми. Педагогічні, публіцистичні та літературні праці, учительський досвід В. Сухомлинського мали величезний вплив на практичну діяльність школи, збагатили педагогіку України новими положеннями і думками, які не втратили актуальності і в наш час та знайшли своє відзеркалення в заявленій нами проблематиці. Варто відзначити, що дослідженням теми професійної підготовки вчителя у процесі вивчення педагогічної спадщини $\mathrm{B}$. Сухомлинського займалося багато вчених як України, так і Росії. Зокрема, це наукові праці С. Білецької, І. Зязюна, Т. Когачевської, А. Луцюка, І. Наливайко, О. Сухомлинської, К. Юр'євої та ін.

Мета статті - розкрити особливості міжкультурної компетентності вчителя іноземних мов, грунтуючись на спадщині В. Сухомлинського.

Виклад основного матеріалу дослідження. Підготовка вчителя 3 іноземної мови включає студента в діяльність, в процесі виконання якої він розвиває різні види компетентності, серед них і міжкультурну. Формування міжкультурної компетентності професійної підготовки вчителів розглядають як педагогічний процес, під час якого існує реальний взаємозв'язок між змістом повідомленої інформації про національно-культурні особливості та практичним застосуванням цієї інформації у різних формах i видах комунікативної діяльності.

Аналіз науково-педагогічної літератури свідчить про те, що як вітчизняні, так і зарубіжні дослідники у галузі педагогіки, соціології, культурології, психології, лінгвістики, філософії та освіти виявляють підвищений інтерес до різних аспектів міжкультурної компетентності. Отже, ми розглядаємо міжкультурну компетентність як інтегральну особистісну характеристику, яка проявляється в стійкості мотивації до вивчення та порівняння рідної культури й культури країни, мову якої вивчаємо.

На основі проведеного аналізу ми виділили такі основні компоненти міжкультурної компетентності: когнітивний; культурологічний; мотиваџійний.

Формування міжкультурної компетентності майбутнього фахівця повинно здійснюватися не лише на засадах компетентісного підходу, а й підсилюватися культурологічним підходом, який, має суттєве значення для визначення шляхів $\mathrm{i}$ тенденцій розвитку міжкультурної компетентності 
майбутнього фахівця. Культурологічний підхід виступає засобом реалізації культурознавчої освіти, завданнями якої при навчанні іноземних мов $є$ : розвиток культури; сприйняття сучасного багатомовного світу; комплексний білінгвістичний і полікультурний розвиток мовної особистості студентів; розвиток у студентів поліфункціональної соціокультурної компетенції; у стратегіях соціокультурного пошуку в незнайомих культурних співтовариствах; у виборі культурно прийнятних форм взаємодії з людьми в умовах сучасного міжкультурного спілкування; розвиток умінь опису рідної культури в термінах, зрозумілих для членів міжнародних співтовариств; навчання технологій захисту від культурного вандалізму, культурної асиміляції, культурної дискримінації; створення умов для культурної творчості.

Міжкультурна компетентність передбачає позитивне ставлення до мови та культури інших народів, усвідомлення цінностей своєї і іншої культури, а також здібності учасників ефективно включатися в діалог культур.

Велика заслуга в реалізації культурологічних знань у процесі професійної

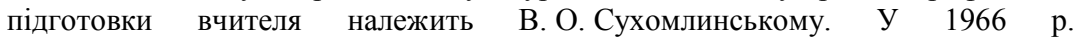
В. Сухомлинський розпочав працювати над книгою про педагогічну культуру вчителя, яку він присвятив вірному другові й колезі - своїй дружині Ганні Іванівні. Цінним у книзі «Педагогічна культура» $\epsilon$ те, що в ній описано педагогічну систему Василя Олександровича, яка охоплює всю багатогранність, сукупність методів і прийомів виховного вплину особи педагога на колектив і вихованця з метою всебічного, гармонійного розвитку особистості. Свій педагогічний досвід з питань професійної підготовки вчителя В. Сухомлинський проаналізував у широковідомих книгах «Павлиська середня школа», «Серце віддаю дітям», «Як виховати справжню людину», «Сто порад учителеві», «Розмова 3 молодим директором школи» і в дисертаційному дослідженні «Директор школи - керівник навчально-виховною роботою» (рос. мовою, 1955), що є скарбницею ідей про педагогічну майстерність учителя, а ще в «Листі дочці» - своєрідному гімні його праці.

Згідно з ідеями видатного педагога культура $є$ потужним чинником соціального розвитку, що впливає на всі сфери суспільної та індивідуальної життєдіяльності: працю, побут, дозвілля, мислення, спосіб життя суспільства й особистості. В. Сухомлинський добре розумів, яке велике значення для школи має вчитель 3 високорозвиненою культурою. Причому він не міг погодитися 3 тією традицією, яка склалася в педагогічній теорії і практиці, - обмежувати питання професіоналізму вчителя лише його професійними знаннями, уміннями i навичками. Такий учитель може непогано виконувати свої обов'язки, але, коли йдеться про виховання, цього занадто мало: цей процес вимагає насамперед усебічно розвиненої особистості. Саме в цьому полягає специфіка педагогічної праці.

3 огляду педагогічних джерел ми зробили висновок, що культурі вчителя іноземної мови повинні бути притаманні такі особливості:

1. Вчитель повинен володіти не тільки методикою викладання іноземної мови, але і бути обізнаним з культурою однієї або декількох зарубіжних країн, мову яких вивчають учні.

2. Вчитель іноземної мови повинен в навчальному процесі виконувати функції носія не тільки вітчизняної, але і зарубіжної культури, демонструвати 
учням різні аспекти культури інших країн, допомагати їм зрозуміти ціннісні сторони цієї культури.

3. Будучи носієм культури конкретної країни, вчитель повинен знати і володіти нормами поведінки, які прийняті в цій країні. Тобто він повинен знати не тільки іноземну мову, але і володіти культурою спілкування країни, мова якої вивчається.

В. Сухомлинський в своїх працях велику увагу приділяв також вивченню іноземних мов. Але багатство, втілене у скарбах мов інших народів, на його думку, залишається для людини неприступним, якщо вона не оволоділа рідною мовою, не відчула їі краси. Чим глибше людина пізнає тонкощі рідної мови, чим тонша іiі сприйнятливість до гри відтінків рідного слова, тим більше підготовлений іiі розум до оволодіння мовами інших народів, тим активніше сприйме ії серце красу слова (Сухомлинський, 1976, с. 175).

У цьому контексті слід звернути увагу ще на один важливий момент. Засвоєння іноземної мови завжди спирається на мовну компетенцію рідної мови, на знання граматики цієї мови, загалом на ії структури. Видатний педагог був глибоко переконаним у тому, що рідне слово відіграє надзвичайно потужну пізнавально-розвивальну роль у формуванні духовного світу, загальної культури та інтелекту людини.

Уміння користуватися словом - основна умова формування мовної компетентності, а тому і культура майбутнього педагога має складатися 3 культури мислення, культури мовлення та комунікативної культури (Янкина, 2003).

Головним у процесі навчання іноземної мови $\epsilon$ не накопичення знань, або, за В. Сухомлинським (1977), «не механічне перекладання знань 3 голови вчителя в голову учня», а навчання мовленнєвій діяльності, навчання мовленнєвому спілкування за допомогою іноземної мови. Такий підхід (найчастіше називається комунікативним) у сучасній методиці $\epsilon$ найбільш умотивованим серед багатьох інших методів навчання іноземної мови (Сухомлинський, 1977).

За висловом В. Сухомлинського (1977), іноземна мова відіграє важливе значення в процесі навчання: по-перше, вона виступає умовою гармонійного розвитку кожного учня; по-друге, вона необхідна учневі як джерело розвитку його індивідуальних нахилів та здібностей. Тож судження В. Сухомлинського стосовно іноземної мови передбачають врахування інтересів та індивідуальнопсихологічних особливостей кожного учня, сприяння реалізації його особистісного потенціалу, розвитку творчих (креативних) умінь і навичок. Власне, на це була спрямована вся педагогічна система Василя Сухомлинського.

Ще однією із провідних ідей В. Сухомлинського $є$ те, що навчання іноземної мови повинно відбуватися при широкому залученні культури. Такий підхід сьогодні ні в кого не викликає сумніву. Для формування іншомовної мовленнєвої діяльності, міжкультурної компетентності недостатньо знати лише мовні одиниці, мовленнєві кліше та певні фрази задля досягнення мети спілкування. Необхідним стає прилучення особистості до іншомовної культури саме в процесі формування іншомовної мовленнєвої діяльності. Вивчення іноземної мови повинно сприяти тому, аби краще розуміти чужий світ i культуру, а водночас чіткіше відчувати власну ідентичність, належність до єдиного національного простору. Уроки 3 лінгвокраїнознавчими елементами 
стимулюють учнів до порівняння власної та чужої культур, до роздумів i висловлювань стосовно особливостей рідного культурного простору. Цей процес можна розглядати як духовну творчість, як когнітивний і креативний акт мовленнєвій діяльності (Сухомлинський, 1977).

Висновки і перспективи подальших розвідок. Беззаперечним $\epsilon$ той факт, що культурологічне спрямування професійної підготовки майбутніх учителів іноземної мови має суттєве значення для визначення шляхів i тенденцій розвитку міжкультурної компетентності майбутнього спеціаліста. Погляди Василя Сухомлинського на значення культури та іноземної мови в процесі навчання та виховання стали основою, яку використовують сучасні педагоги для розвитку міжкультурної компетентності сучасного вчителя іноземної мови.

\section{СПИСОК ВИКОРИСТАНИХ ДЖЕРЕЛ:}

Сухомлинський, В. (1976). Проблеми виховання всебічно розвиненої особистості Т. 1. Київ: Радянська. школа. с. 55-206.

Янкина, Н. (2003). Формирование готовности студента университета $\kappa$ интеркультурной коммуникаџии. Санкт-Петербург: Рос. гос. пед. ун-т. 120 с.

Сухомлинський, В. (1977). Вибрані твори в п’яти томах. Т. 5. Київ: Радянська школа. 639 с.

Гурмаза, В. (2007). Роль міжкультурного аспекту у викладанні іноземної мови. В: Підвищення рівня науково-дослідної діяльності обдарованої молоді. Миколаїв: МДАУ. с. 32-33.

Садохин, А. (2008). Компетентностный подход в диалоге культур: сущность и базовые показатели. В: Межкультурный и межрелигиозный диалог в целях устойчивого развития. Москва: РАГС. с. 251-255. c. $9-279$.

Сухомлинський, В. (1977). Серце віддаю дітям. Т. 5. Київ : Радянська школа.

\section{REFERENCES:}

Sukhomlynskyi, V. (1976). Problemy vykhovannia vsebichno rozvynenoi osobystosti. T. 1. [Issues of Education of a Highly Developed Person]. Kyiv: Radianska shkola. s. 55-206. [in Ukrainian]

Yankina, N. (2003). Formirovanie gotovnosti studenta universiteta $k$ interkulturnoy kommunikatsii [Formation of University Student' Readiness for Intercultural Communication]. Sankt-Peterburg: Ros. gos. ped. un-t. 120 s. [in Russian]

Sukhomlynskyi, V. (1977) Vybranni tvory v piaty tomakh. T. 5. [Selected Works in 5 Volumes]. Kyiv: Radianska shkola. 639 s. [in Ukrainian]

Hurmaza, V. (2007) Rol mizhkulturnoho aspektu u vykladanni inozemnoi movy [The Role of the Intercultural Aspect in Teaching a Foreign Language]. V: Pidvyshchennia rivnia naukovo-doslidnoi diialnosti obdarovanoi molodi. Mykolaiv: MDAU. s. 32-33. [in Ukrainian]

Sadokhin, A. (2008). Kompetentnostnyy podkhod v dialoge kultur: sushchnost i bazovye pokazateli [Competence Approach in the Dialogue of Cultures: the Essence and Basic Indicators] V: Mezhkulturnyy $i$ mezhreligioznyy dialog $v$ tselyakh ustoychivogo razvitiya. Moskva: RAGS. s. 251-255. [in Russian]

Sukhomlynskyi, V. (1977). Sertse viddaiu ditiam. T. 5. [I Give My Heart to Children]. Kyiv : Radianska shkola. s. 9-279. [in Ukrainian] 


\title{
V. O. SUKHOMLINSKY'S VIEWS ON INTERCULTURAL COMPETENCE OF FOREIGN LANGUAGE TEACHERS
}

\author{
Svitlana Denysova \\ Lecturer of Foreign Language \\ Lutsk Pedagogical College \\ Lutsk, Ukraine \\ ORCID: 0000-0001-9352-7036 \\ e-mail: 1denusova.svitlana@ukr.net
}

Oksana Kuzmych

Lecturer of Foreign Language Lutsk Pedagogical College, Lutsk, Ukraine

ORCID; 0000-0002-1335-3791

e-mail: kuzmych.o@ukr.net

Iryna Nikolayeva

Lecturer of Foreign Language Lutsk Pedagogical College,

Lutsk, Ukraine

ORCID: 0000-0002-2949-0002

e-mail:iri5272@ukr.net

\begin{abstract}
The article is devoted to the concept of intercultural competency in the process of professional training of a foreign language teacher. It is noted that cultural direction of the professional training of future teachers of a foreign language is essential to determine the ways and tendencies of developing the intercultural competence of a future specialist. In the course of research, the main components of the intercultural competence were identified: motivational, cognitive and cultural. The article states that the preparation of a modern foreign language teacher in European countries, including in Ukraine, should have a distinctive culturological character and be aimed at developing the abilities of adaptive behavior in communication with the culture bearers of the country, the language of which is being studied, and also on the formation of mentality, style of behavior, traditions and customs of the people on the basis of language knowledge. It is emphasized that the main thing in learning a foreign language is not just the accumulation of knowledge but teaching of speech communication with a help of foreign languages. Vasyl Sukhomlinsky's ideas about the content and development of intercultural competence of a foreign language teacher are considered. In the accordance with the words of a great teacher, a foreign language plays an important role in the process of learning: it is a condition for the harmonious development of each student; it is necessary for the student as a source of development of his/her individual skills and abilities. According to Sukhomlinsky, studying a foreign language should helps to understand the world and culture of other people better, and at the same time to feel more clearly its own identity, belonging to a single national space. The views of the scientist on the values of culture and foreign language in the process of education and upbringing, which are used by modern educators to develop the intercultural competence of a modern foreign language teacher, are also presented.
\end{abstract}

Key words: culture, intercultural competence, teacher, foreign language, culturological approach, communication.

Стаття надійшла до редакиії 22.03.2019 р. 